DIW BERLIN

Discussion Papers
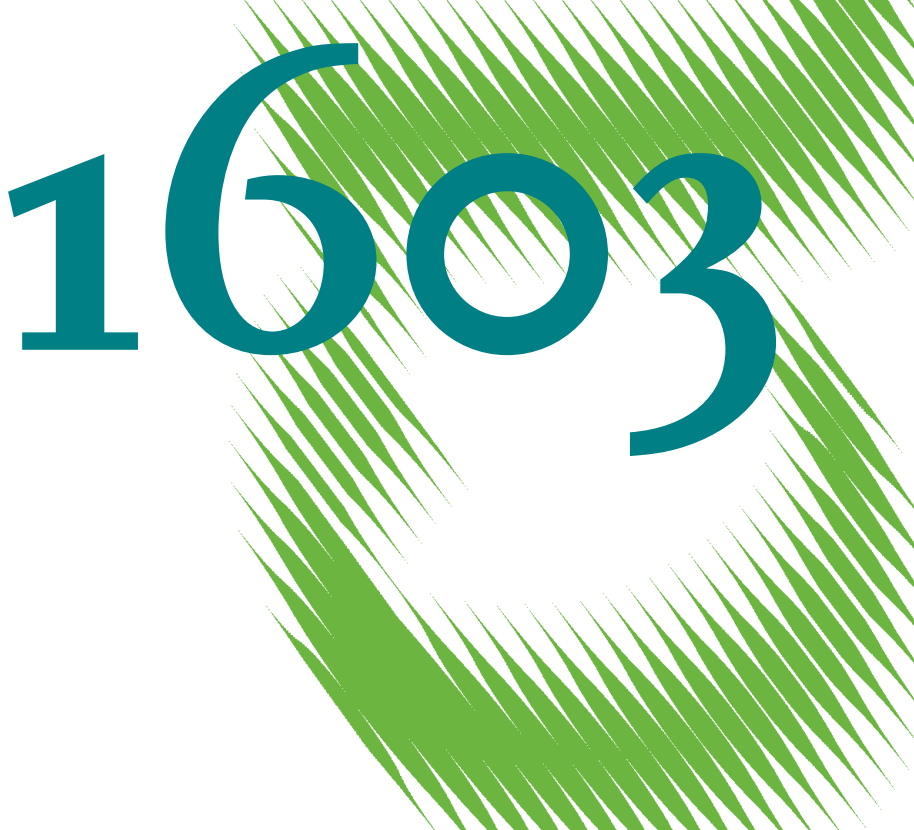

The Family Working Time Model

- Toward More Gender Equality in

Work and Care 
Opinions expressed in this paper are those of the author(s) and do not necessarily reflect views of the institute.

IMPRESSUM

(C) DIW Berlin, 2016

DIW Berlin

German Institute for Economic Research

Mohrenstr. 58

10117 Berlin

Tel. +49 (30) $89789-0$

Fax +49 (30) $89789-200$

http://www.diw.de

ISSN electronic edition 1619-4535

Papers can be downloaded free of charge from the DIW Berlin website:

http://www.diw.de/discussionpapers

Discussion Papers of DIW Berlin are indexed in RePEc and SSRN:

http://ideas.repec.org/s/diw/diwwpp.html

http://www.ssrn.com/link/DIW-Berlin-German-Inst-Econ-Res.html 


\title{
The family working time model - toward more gender equality in work and care
}

\author{
Kai-Uwe Müller, Michael Neumann, Katharina Wrohlich
}

July 2016

\begin{abstract}
:
Since the millennium, the labor market participation of women and mothers is increasing across European countries. Several work/care policy measures underlie this evolution. At the same time, the labor market behavior of men and fathers, as well as their involvement in care work, is relatively unchanging, meaning that employed mothers are facing an increased burden with respect to gainful employment and providing care. We propose a family working time model that incentivizes fathers and mothers to both work in extended part-time employment. It provides a benefit in form of a lumpsum transfer or income replacement for each parent if, and only if, both parents work 30 hours per week. Thus, it explicitly addresses fathers and - contrary to most conventional family policies actively promotes the dual earner/dual carer paradigm. Combining microsimulation and labor supply estimation, we empirically analyze the potential of the family working time model in the German context. The relatively small share of families already choosing the symmetric distribution of about 30 working hours would increase by 60 per cent. By showing that a lump-sum transfer especially benefits low-income families, we contribute to the debate about redistributive implications of family policies. The basic principles of the model generalize to other European countries where families increasingly desire an equal distribution of employment and care. In order to enhance the impact of such a policy, employers' norms and workplace culture as well as the supply of high-quality childcare must catch-up with changing workforce preferences.
\end{abstract}

Key-Words: care work, gender equality, family policy, labor supply

\author{
Correspondence to: \\ Kai-Uwe Müller \\ German Institute for Economic Research (DIW Berlin) \\ Mohrenstraße 58, 10117 Berlin \\ kwrohlich@diw.de
}

Word count: 9,762 (all inclusive)

We thank Agnes Blome for many valuable comments and suggestions on an earlier version of this paper. We also gratefully acknowledge funding by the Friedrich-Ebert-Stiftung as well as the Hans Böckler Foundation. These foundations played a pivotal role in developing the family working time model that is introduced and analyzed in this article. 


\section{Introduction}

Since the start of the millennium, many European countries are promoting policies aimed at "reconciling work and family" (Lewis, 2009; Ferragina and Seeleib-Kaiser, 2015). In most cases, these policies seek to enable women to enhance their labor market participation or to work longer hours. It is high on political agendas, not least due to the demographic change and the shortage of skilled labor. Policies in this context include a variety of measures, such as increasing the availability of public or publicly subsidized child care, facilitating access to part-time employment, and parental leave programs. ${ }^{1}$ Some of these policies do indeed enhance women’s labor market activities (Boeckmann et al., 2015; Budig et al., 2012). They contribute to the decline of the male breadwinner model which is replaced with the rise of the one and a half earner model in Europe (Lewis et al. 2008; Pollmann-Schult, 2016; for Germany Ciccia and Bleijenbergh, 2014). This is strengthening women's economic independence and career prospects.

Despite of their success regarding women's labor market attachment, these policies designed to "reconcile work and family" have barely influenced paternal behavior. The labor force participation rate and the employment rate of women increased from, respectively, around $55 \%$ and $50 \%$ at the beginning of the 1990s to about $72 \%$ and $66 \%$ in 2014 (EU-28 average, Figure 1). On the other hand the labor force participation rate, like the employment rate, of men remained fairly constant at around $85 \%$ and $78 \%$ over the same time period. Although intentionally formulated in a genderneutral way, the available evidence shows that these policies have not succeeded in activating paternal commitment to child care. ${ }^{2}$

Given that men have barely changed their working behavior, women's heightened labor market attachment entails potentially negative consequences for families and, in particular, women with respect to time and care squeeze (Lewis et al. 2008). Despite evidence stressing the link between

\footnotetext{
${ }^{1}$ For an overview of policies promoting employment of parents, see OECD (2011).

${ }^{2}$ Bünning and Pollmann-Schult (2016) show in a cross-country comparison that working hours (not labor market participation) of fathers changed to a small extent in those countries that offer well paid, nontransferable parental leave for fathers and short parental leave for mothers.
} 
more equality in employment and domestic work, women are still responsible for the largest part of non-market, mostly care, work (Bühlmann et al., 2010; van der Lippe et al., 2011). The gender gap in unpaid work is often argued to be one of the underlying reasons why gender equality in various dimensions of the labor market, e.g. earnings and career opportunities, remains a goal unachieved (Pascall and Lewis, 2004; Pettit and Hook, 2009).

Figure 1 Development of male and female labor force participation rate, 1990 - 2014 in EU-28 countries (age group 25-64)

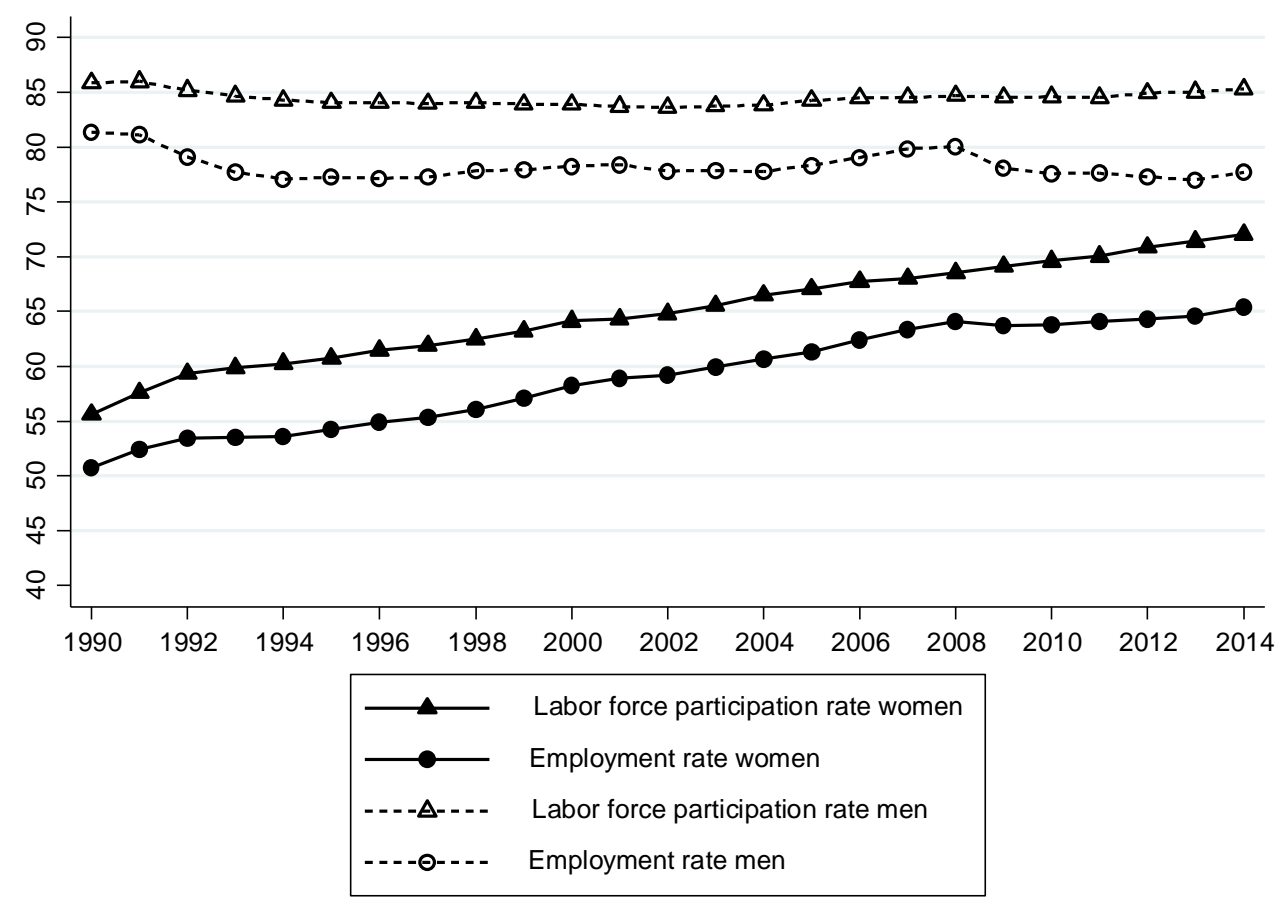

Source: OECD Statistics, 2016; own calculations.

Scholars point to the societal problems that come with the move from the male breadwinner model to that of either the dual earners or the one and a half breadwinner model (Crompton, 1999; PfauEffinger, 1999; Gornick and Meyers, 2003; Morgan, 2008). The dual earner/dual carer model ${ }^{3}$ is often suggested as an approach to time allocation that could achieve greater gender equality in the labor market and in the distribution of care duties (see, among others, Gornick and Meyers, 2003). The

${ }^{3}$ This model is sometimes also called universal caregiver model (Ciccia and Verloo, 2012). 
discussion about how to share care work more equally between mothers and fathers is also now subject to public debate. Several European countries are debating policies directed at increasing the men's share of care work. The most prominent example is the introduction of "daddy months" or a "daddy quota" in parental leave schemes. A chunk of the paid parental leave time is granted exclusively to fathers and cannot be transferred to mothers, thus generating financial incentives for men to provide more care work. These regulations are part of parental leave schemes in many European countries (Huerta et al., 2013; Ekberg et al., 2013). ${ }^{4}$ However, the impact of these schemes on paternal child care involvement is generally very limited. ${ }^{5}$

Thus, the aim of this article is to put forward the family working time model for discussion as a new, complementary, and more radical concept to promote and incentivize the dual earner/dual carer model. Originally developed for Germany, we argue that the underlying principles generalize to other contexts: At the heart of the model lies the idea that fathers and mothers share market and care work equally. Both parents individually generate an income that ensures a minimum standard of living. Therefore, they should both be able to devote the necessary amount of time to gainful employment, while, at the same time, their respective working hours should be short enough to avoid a time (care) squeeze that otherwise faces the two full-time working parents.

The family working time model presupposes that fathers and mothers engage in market work of about 30 hours per week. ${ }^{6}$ This implies a shift from the one and a half earner model prevalent in (West) Germany and many other European countries to the two times three quarters earner model (Pascall and Lewis, 2004). Parents who choose this model both receive a financial benefit that

\footnotetext{
${ }^{4}$ For an overview, see OECD, 2011.

${ }^{5}$ Huerta et al. (2013) show that fathers who take parental leave are also slightly more likely to be involved in child-care tasks (see Bünning and Pollmann-Schult (2016) for evidence on Germany). However, Huerta et al. (2013) do not control for the endogeneity of fathers' leave taking. A study by Ekberg et al. (2013) on Sweden, where selection into leave taken by fathers is controlled for, finds that there is no evidence for a causal relationship of paternal leave taking on involvement in child care tasks at later ages. See also Kleider (2015) for the impact of social policies on labor market inequality.

${ }^{6}$ This seems to match working hours preferences; see both section 2 below as well as Steiber and Haas (2015).
} 
incentivizes them to adjust their working hours accordingly. The benefit also provides financial support to parents with low earnings who could otherwise not afford this working time combination. It is paid individually to mothers and fathers if, and only if, both partners choose to work about 30 hours per week.

Subsidizing this symmetric parental working time arrangement is intended to promote gender equality on the labor market. This model only works under the prerequisite that child care facilities of good quality are readily available for parents. Nevertheless, it values private care work highly, emphasizing that child care cannot solely be a responsibility shared by mothers and external child care providers (be it state or private institutions). Fathers must also do their share of care work if gender equality is actually going to be achieved.

A first contribution of this article is to introduce the family working time model as an alternative approach into the broader debate about policies promoting equality in gainful employment and house-work. Eligibility requirements and the design of financial incentives are discussed in detail. We distinguish two alternatives regarding the configuration of the subsidy: a benefit replacing (parts of) forgone earnings vs. a lump sum transfer. As a second contribution, we address the question of which behavioral reactions the introduction of the family working time model would induce. We specify and estimate a structural labor supply model that is used to simulate the effects of this policy. According to our simulations, the overall share of families opting for such a working time arrangement would increase from a moderate level by about $60 \%$. A third contribution is the special focus of our empirical analysis on distributional issues. Total effects are decomposed by region, quartiles and number of children. Although implying similar overall effects, we show that a lumpsum transfer is more favorable for low-income households than an income-related benefit. Thereby, different versions of the family working time model are related to the emerging literature examining gender and class inequality (Hook, 2015). 
The remainder of the article is structured as follows. After a brief review of other policies promoting the dual earner/dual carer model, the following section provides descriptive evidence on actual and desired working hours across Europe. The family working time model is introduced in section 3 . The micro-econometric analysis of the expected behavioral effects is detailed in section 4 including a discussion of the results from various policy simulations. Section 5 concludes by putting the model and empirical findings into a more general perspective, relating it to the policy debate in Europe, and highlighting limits of the analysis as well as allies for future research.

\section{The dual earner/dual carer model in European countries: policies and time preferences}

As noted in the introduction, policies seeking to "balance labor market and family life," even if formulated in a gender-neutral way, mostly affect mothers; paternal behavior remains unaffected. Paid parental leave schemes are a striking example: All European countries provide some form of paid parental leave for parents with young children (OECD, 2011). In most cases, there is a short period of maternity leave; i.e. paid time off that is reserved for mothers around childbirth. After this, many countries provide paid leave entitlements that can be used by fathers or mothers. Due to prevailing social norms of mothers as primary care givers (Boeckmann et al., 2015; Steiber and Haas, 2012), as well as economic reasons (on average, mothers have lower earnings than their male partners, see e.g. Aisenbrey and Bruckner, 2008), the vast majority of this leave is taken by mothers (OECD, 2011). This applies even to countries that provide income-replacement benefits.

Thus, some countries (for example, Sweden, Norway, Finland, Denmark, Austria and Germany) have introduced leave entitlements that can only be used by fathers. These so-called "daddy months" cannot be transferred to mothers. The overall period of father-specific leave is relatively short 
(usually one or two months) compared to the total amount of available parental leave. ${ }^{7}$ Empirical evidence shows that fathers are more inclined to take parental leave in countries that have parental leave entitlements specifically reserved for fathers (see, e.g. Bünning and Pollmann-Schult, 2016). Only a very small share of fathers, however, takes leave that is longer than the time explicitly reserved for fathers (Geisler and Kreyenfeld, 2011, for the German example).

The dual earner/dual carer model is not the common model in Europe (Ciccia and Verloo, 2012), not even in the Nordic countries. In Sweden, which introduced "daddy months" within parental leave in the 1980 s, women still do 1.6 times as much care work as men, but only 0.7 times as much market work. Care work is split even more unequally in European countries where family policies do not explicitly promote gender equality (Hipp and Leuze, 2015). In Germany, Italy and Spain, for example, women do 1.9, 2.3, and 1.7 times as much care work as men, respectively, while they engage in much less market work ( 0.6 times the hours of men in Germany and in Spain, 0.5 times in Italy). ${ }^{8}$

As of 2016, the prevalent mode of time allocation in many European countries is still the one and a half breadwinner model. Multiple surveys show that this reality does not match young parents' wishes. Using the 2005 European Social Survey (ESS), Lewis et al. (2008) report that more than $60 \%$ of working fathers across 13 European countries wish to reduce their working hours, while mothers mostly want "long part-time" employment. This basic pattern still holds using more recent data (Steiber and Haas, 2015). Moreover, attitudes toward the distribution of paid and unpaid work vary across and even within welfare regimes (Edlund und Öun, 2016; Pollmann-Schult, 2016).

A closer look at 2010 ESS data for a sample of cohabiting couples with at least one child within the household confirms these findings in principle, but also conveys a more nuanced picture (Table A1 in the Appendix). First, it shows that employed women and men exhibit distinctly different hours

\footnotetext{
${ }^{7}$ Detailed accounts on the regulations of parental leave schemes in different OECD countries are given by Ray et al. (2010), Dearing (2016), and OECD (2011).

${ }^{8}$ OECD Family database (www.oecd.org/social/family/databases; retrieved April 25, 2016).
} 
patterns across all countries in the sample: about $49 \%$ of women have jobs below 35 hours per week while only about $45 \%$ are above this threshold ( $6 \%$ do not work). The share of full-time working women is below-average in Great Britain or the Netherlands but above-average in most Southern (conditional on a lower overall participation rate here), Nordic, and Eastern European countries. By contrast, only about $20 \%$ of men work at most 35 hours and about $80 \%$ are in full-time employment. The male full-time share (defined as more than 35 hours per week) is higher in almost all countries, with France a notable exception at about 45\%.

Second, the difference between actual and desired working hours exhibits common patterns for men and women in virtually all countries: The share of people preferring to increase their hours is higher, the lower their actual working hours are. Conversely, the share of people wishing to reduce their work hours increases the more hours they actually work. Significant shares of the population regard themselves as underemployed or overemployed. However, the overall share of fathers (mothers) who would like to extend (reduce) their working hours is larger in all hours categories than the fraction of mothers (fathers). This gender difference exists in all countries.

Third, given the contrast in actual working hours, a larger share of mothers would like to expand their hours of work. On the other hand, a larger share of fathers would rather reduce their working hours. At the same time full-time employed mothers and part-time employed fathers would increase and decrease their hours, respectively. Lewis et al.'s (2008) conclusion that a gender equal distribution of employment and care is not achieved but desired still holds. An increasingly preferred arrangement seems to be the two times three-quarter employment model. The degree this arrangement is desired varies across the countries in our sample.

The same data set also provides information on the distribution of house and care work. Individuals are asked about their own hours spent on these activities as well as their respective partners'. Answers are quite consistent across mothers and fathers: women shoulder about 2.5 times the workload in the household compared to their male partners. There are considerable differences in 
mothers' total hours spent on house and care work with longer hours worked in Southern and Eastern European countries and shorter hours in Nordic countries, France, and Great Britain. Another finding is that the volume of housework shouldered by employed mothers barely varies with their working hours. Full-time employed mothers face almost the same amount of house and care work as mothers working in part-time jobs with low working hours. These findings underline the problem of the time squeeze for mothers with full-time jobs.

\section{The family working time model: financial incentives for the dual earner/dual carer} model

In recent years the discrepancy between actual working hours of parents with young children and their wishes regarding working time arrangements is increasingly discussed by the public, not least as an important dimension of the gender pay gap (Ponthieux and Meurs, 2015). Consequently the basic principles of the "family working time model" ("Familienarbeitszeit") evolved from discussions with practitioners initiated by the Friedrich-Ebert-Stiftung (FES) and the Hans Böckler Stiftung (HBS) (Müller et al., 2013). This process also caught the attention of the Federal Ministry for Family Affairs, Senior Citizens, Women and Youth. Elements from the model were integrated in the 2014 reform of parental leave regulations in Germany (see Geyer and Krause 2016). The concept will also likely be part of the 2017 Social Democratic Party (SDP) campaign platform. ${ }^{9}$

The core idea of the family working time model is to pay financial benefits to couples if, and only if, both partners work about 30 hours per week. Should only one partner choose this amount of working time and the other one works either more (e.g. full-time at 40 hours) or less (e.g. part-time at 20 hours or less), neither is granted the benefit. By conditioning the financial subsidy on the positive (observable) market work hours of both partners, it sets strong financial incentives for the

${ }^{9}$ On July 18, 2016, Federal Minister for Family Affairs Manuela Schwesig (member of the Social Democratic Party) presented a variant of the family working time model very similar to the one analyzed here (http://www.welt.de/politik/deutschland/article157143007/Schwesig-propagiert-ihr-neuesFamiliengeld.html). 
dual earner/dual carer model. The benefit is tied to a specific working-time arrangement where both parents work equal amounts. At the same time it equips parents with sufficient financial resources to provide care work. Unlike other cash-for-care benefits, e.g. the "Betreuungsgeld" in Germany (Müller and Wrohlich, 2016), the subsidy does not imply negative work incentives for secondary earners with zero or low working hours, who are usually identical with mothers.

This concept is, in principle, universally applicable to various family and care work settings. However, to keep fiscal costs reasonable, in this paper we assume that the benefit could be drawn by parents for up to three years after parental leave benefits have expired. In the German case, this period used to start when the child is either 12 or 14 months old (depending on the utilization of daddy months). After 2014 parental leave reform, the period could start as late as when the youngest child is 28 months old because parental leave benefits can be stretched out when both parents work part-time (Geyer and Krause, 2016). ${ }^{10}$

We distinguish two versions of the family working time model (in the following referred to as scenarios $A$ and $B$ ) in terms of the benefit design. In scenario A, each parent receives a subsidy that replaces part (for mean incomes about 65\%) of the difference in net earnings between working fulltime and an extended part-time position of 30 hours. When, e.g., a full-time working individual who earns a middle income decides to reduce his or her working hours from 40 hours to 30 hours per week, $65 \%$ of his or her net earnings forgone after the reduction of hours are compensated by the subsidy. The simpler scenario B consists of a lump-sum benefit amounting to 250 Euro per month for each parent as long as both are eligible according to the working time condition. In both scenarios the transfers are not means-tested. The implied incentives for different incomes can be visualized by replacement rates drawn as a function of the net earnings (Figure 1).

\footnotetext{
${ }^{10}$ Since our data refer to the 2010 to 2012 period, when the previous regulation was in place, we analyze the first three years after the child reaches its first birthday. Otherwise we would also have to make assumptions about the take-up of part-time parental leave benefits. Likewise, we abstract from the optional two daddy months as well as the prolongation of parental leave without benefits under the old regulation.
} 
Figure 2 Replacement rate as a function of net earnings

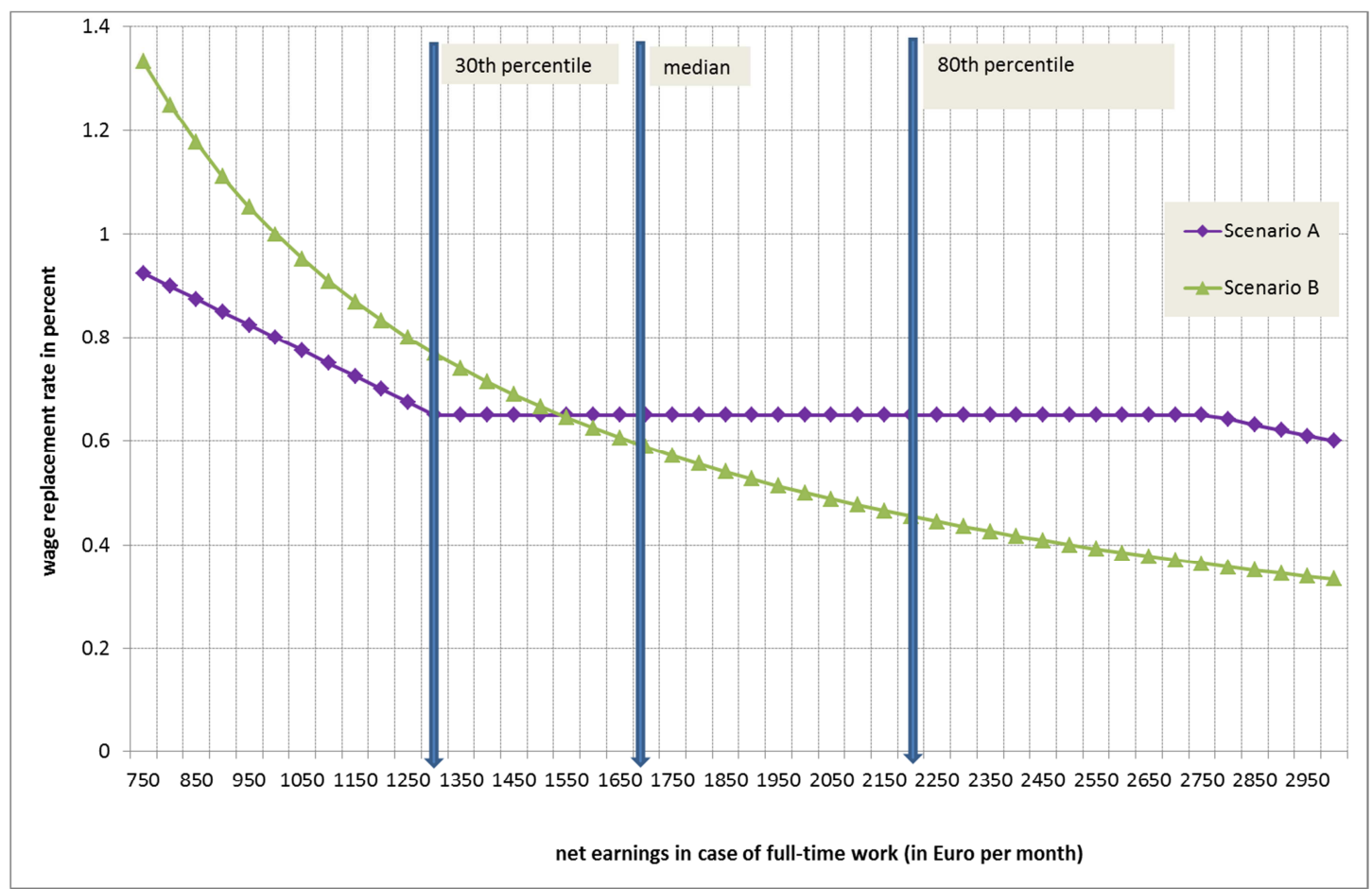

Source: Own calculations.

In scenario $\mathrm{A}$, the benefit replaces a portion of the difference in net earnings between full-time and extended part-time employment of about 30 hours per week. The replacement rate amounts to $65 \%$ for those with middle incomes and increases at 0.05 percentage points per Euro for parents with low incomes (net earnings below 1,300 Euro per month, corresponding to the $30^{\text {th }}$ percentile). The benefit is capped at 360 Euro per month and per parent for high income households. This implies a decrease of the replacement rate that starts at a net income of 2,750 Euro per month. ${ }^{11}$ Note that the benefit replaces the difference between potential net earnings at 30 hours of market work and fulltime employment. All persons are entitled to this benefit, regardless of their prior employment status. ${ }^{12}$

\footnotetext{
${ }^{11}$ This replacement rate scheme was chosen since it is the same as in the parental leave scheme in Germany that is paid to parents during the first 12-14 months after a child is born.

${ }^{12}$ In practice, net earnings at 30 hours per week and full-time employment are simulated on the basis of individual wage rates.
} 
In scenario B, each parent is paid a lump-sum transfer of 250 Euro per month as long as both parents meet the working time condition. This amount is roughly equal to the average amount of the benefit under scenario A. Scenarios A and B imply more or less the same short-term fiscal costs, thus allowing for direct comparisons of any behavioral reactions induced by them. Although the lump sum benefit does not depend on monthly earnings, there is an implicit replacement rate that can be compared to scenario A (Figure 1).

A benefit that replaces a significant proportion of foregone earnings, as in scenario $\mathrm{A}$, is more appealing to middle and high income parents, in particular fathers. Empirical evidence from the evaluation of parental leave schemes shows that fathers respond more to benefits that replace a high proportion of their earnings rather than to a lower lump-sum rate (Geyer et al., 2015). On the other hand, a lump-sum benefit, as in scenario B, is more favorable to low income families, thus potentially reducing overall inequality. Moreover, it comes at a much lower bureaucratic cost, both for families and for the administration authorities. ${ }^{13}$

The family working time model is meant to set incentives for a specific allocation of market and care work within couples. Thus, it is not straight-forward how to extend the concept to single parents. Different possibilities are under discussion. ${ }^{14}$ We define single parents here as adult parents who live in the same household with their dependent children but without other adults and who are granted the single parents' tax allowance. These single parents are also eligible for the benefit up to three years after parental leave. The benefit is conditional on their working hours, i.e. they have to work about 30 hours per week. The working time of the other parent not living in the household is not relevant. We do not include results for singles in the empirical section of this paper because the focus

\footnotetext{
${ }^{13}$ This is particularly true in the context of scenario A, where the benefit is calculated based on a comparison between potential net earnings at 30 hours of market work and net earnings at full-time work.

${ }^{14}$ It is suggested to give single parents the option to share care responsibilities with persons other than their spouse or partner. These could be neighbors, grandparents, or new partners with who mothers do not live with. Due to a lack of data, we are not able to operationalize this suggestion in the empirical analysis.
} 
here is on the distribution of market and household work within couples. ${ }^{15}$ Nevertheless, the family working time model is designed as a comprehensive approach to promote gender equality and, thus, includes single parents.

\section{Empirical analysis}

The empirical analysis of behavioral effects that the family working time model potentially induces is based on a representative sample of families in Germany and a microsimulation model. First, using a tax-transfer simulation model, net household incomes are computed under the status quo legislation and under the two family working time model scenarios. Second, taking the simulated incomes in the status quo, we estimate a micro-econometric household labor supply model. The preferences estimated in this model in combination with simulated net incomes under the policy reform scenarios are then used to predict labor supply reactions of mothers and fathers to the policy reform, i.e. the implementation of the family working time model.

\section{Data and sample}

The microsimulation model is based on data from the German Socio-Economic Panel (SOEP, see Wagner et al., 2007) and the SOEP supplement "Families in Germany" (FID, see Schröder et al., 2013). The SOEP is a representative longitudinal study of private German households carried out since 1984. The FID supplement, which started in 2010, focuses on households with children in Germany, in particular low-income families, families with three or more children, single parents, and families with children born after between 2007 and 2010.

\footnotetext{
${ }^{15}$ Empirical results for single mothers are available from the authors upon request. The family working time model similarly applies to single fathers; these are not quantitatively important in Germany, though. Therefore we cannot conduct a separate analysis for them. The same holds for same-sex couples with children who would also be eligible. Due to size restrictions, we cannot deal with them in the empirical analysis here.
} 
We restrict the sample to families with children aged 1 to 3 years for the empirical analysis. The SOEP and FID combination yields a sample of about 1,900 households per year, which represent roughly 1.7 million families in Germany. Since we pool three waves of the data between 2010 and 2012, we end up with a sample size of roughly 5,500 observations (Table 1). We then select couples with flexible ${ }^{16}$ labor supply for the estimation. Individuals who are self-employed, in school, vocational training, or retired are excluded from the empirical analysis. Thus, the final estimation sample consists of 3,355 observations. Some of the families appear in multiple years. In total, the record entails observations of 2,064 unique couples. The simulation of the reform effects is based solely on 2012 data.

Table 1 Description of the sample

\begin{tabular}{l|c|c|c|c}
\hline Group & $\begin{array}{c}\text { Number of } \\
\text { observations }\end{array}$ & Share in \% & Extrapolation & Share in \% \\
\hline Families with children aged 1-3 & 4,465 & 100.00 & $3,533,726$ & 100.00 \\
Thereof: & 4,105 & 91.94 & $3,230,180$ & 91.41 \\
Not self-employed & 4,100 & 91.83 & $3,228,563$ & 91.36 \\
Non-negative income & 4,098 & 91.78 & $3,221,925$ & 91.18 \\
Mother and father younger than 65 years & 3,355 & 75.14 & $2,656,495$ & 75.18 \\
Flexible labor supply & 2,064 & & & \\
\hline Different couples & & & \\
\hline
\end{tabular}

Source: SOEP 2010, 2011, 2012; FiD 2010, 2011, 2012; own calculations.

Between 2010 and 2012 only 1.15\% of all families with children aged 1 to 3 years chose a working time arrangement in which both partners worked around 30 hours per week (Table 2). This share is much larger in East Germany (4.2 \%) than in West Germany (0.4 \%). Other working hours arrangements with equal market work are also relatively rare. Both parents work full-time in only $4.4 \%$ of all couples with children in this age group. However, the share increases to almost $10 \%$ when overtime is also subsumed as full-time.

\footnotetext{
16 "Flexible," in this context, means that individuals are able to choose their working hours and are, e.g., not (fully) disabled, self-employed, or pensioners.
} 
Table 2 Distribution of families across working hours categories in couple households

\begin{tabular}{|c|c|c|c|c|}
\hline \multirow[t]{2}{*}{ Mother's Working Time } & \multirow[t]{2}{*}{ Father's Working Time } & \multicolumn{3}{|c|}{ Observed Share (\%) } \\
\hline & & Total & West & East \\
\hline 0 & 0 & 3.35 & 3.26 & 3.82 \\
\hline Marginal Employment & 0 & 1.54 & 0.03 & 9.21 \\
\hline Small Part-time & 0 & 0.31 & 0.30 & 0.34 \\
\hline Large Part-time & 0 & 0.88 & 0.87 & 0.85 \\
\hline Full-time & 0 & 2.39 & 2.86 & 0.00 \\
\hline 0 & Small Part-time & 0.16 & 0.10 & 0.44 \\
\hline Marginal Employment & Small Part-time & 0.30 & 0.36 & 0.00 \\
\hline Small Part-time & Small Part-time & 0.90 & 1.08 & 0.00 \\
\hline Large Part-time & Small Part-time & 0.13 & 0.16 & 0.29 \\
\hline Full-time & Small Part-time & 0.55 & 0.66 & 0.00 \\
\hline 0 & Large Part-time & 3.56 & 3.91 & 1.83 \\
\hline Marginal Employment & Large Part-time & 0.7 & 0.84 & 0.00 \\
\hline Small Part-time & Large Part-time & 0.82 & 0.98 & 0.00 \\
\hline Large Part-time & Large Part-time & 1.15 & 0.42 & 4.23 \\
\hline Full-time & Large Part-time & 0.49 & 0.52 & 0.93 \\
\hline 0 & Full-time & 17.20 & 18.20 & 12.11 \\
\hline Marginal Employment & Full-time & 4.81 & 5.65 & 0.48 \\
\hline Small Part-time & Full-time & 7.54 & 8.42 & 3.04 \\
\hline Large Part-time & Full-time & 6.75 & 5.6 & 12.63 \\
\hline Full-time & Full-time & 4.42 & 2.66 & 13.42 \\
\hline 0 & Overtime & 20.02 & 21.48 & 12.55 \\
\hline Marginal Employment & Overtime & 6.54 & 7.81 & 0.07 \\
\hline Small Part-time & Overtime & 5.91 & 5.95 & 5.72 \\
\hline Large Part-time & Overtime & 4.69 & 4.2 & 7.21 \\
\hline Full-time & Overtime & 4.84 & 3.66 & 10.83 \\
\hline
\end{tabular}

Source: SOEP 2012; FiD 2012; own calculations.

Notes: Marginal Employment: 1-14 hours; Small Part-time (mothers): 15-24 hours; Small Part-time (fathers): 1-24 hours; Large Part-time: 25-35 hours; Full-time: 36-40 hours; Overtime: $>40$ hours.

Again, there are large differences between East and West Germany: While the dual breadwinner model, with both parents working full-time, is not common in West Germany (2.7 \%), it is more widely spread in East Germany (13.4\%). The largest share of couples with children aged 1 to 3 in Germany still choose the male breadwinner model: In more than $37 \%$ of the families, the mother does not engage in market work while the father works either full-time (17\%) or even overtime (20\%). Almost 25\% stick with the one and a half breadwinner model, where the mother works short part-time hours and the father works full-time or overtime.

\section{Methodology}

We employ a microsimulation model for the empirical analysis that accounts for behavioral responses of fathers and mothers in terms of their labor supply. The first part of the microsimulation 
model consists of a tax-transfer model that calculates net incomes for all households of the micro data set based on comprehensive information on all sources of income and household characteristics. The tax-transfer model used for this exercise is the STSM ("Steuer-Transfer-Simulations-Modell", see Steiner et al., 2012). This model incorporates all relevant elements of the German tax and transfer system, in particular the income tax, social security contributions, and social transfers. Based on this model, net household incomes are calculated for the status quo legislation as well as for the two family working time benefit scenarios previously introduced. Moreover, in preparation for the labor supply estimation part, net household incomes are not just calculated for the observed working hours of the parents, but also for other hypothetical working hours categories (Table 2). In order to simulate net household incomes in all working hours categories, even for families in which one or both parents are not observed to be working, hourly wages have to be estimated. ${ }^{17}$

The second element of the microsimulation model consists of a micro-econometric labor supply model depicting the employment choices of mothers and fathers as a simultaneous decision. We specify the joint employment decision in a discrete choice framework (van Soest, 1995): A couple selects among several alternatives made up of various combinations of the partners' working hours, corresponding leisure time, and associated net income. Note that "leisure" in this specification includes home production and care work.

The labor supply model for couple households is based on a unitary framework. The underlying assumption is that the spouses maximize a joint utility function in the arguments of net household income and the partners' leisure times. ${ }^{18}$ Assuming a linear-quadratic functional form, the utility index $U$ of family $i$ for a particular choice category $k$ can formally be described as

\footnotetext{
${ }^{17}$ For non-employed individuals in the sample, his or her potential wage rate needs to be estimated. We employ a Heckman-style selection correction model (Heckman, 1979). Results from the wage estimation can be obtained from the authors upon request. See also Steiner et al. (2012) for a general documentation of the wage estimation and Müller et al. (2015) for one in the context of the family working time model.

${ }^{18}$ Obviously, the assumption that both spouses maximize a joint household utility function is rather restrictive. Bargaining models that allow for individual utility functions for each spouse, however, are
} 
$U_{i k}=X_{i k}{ }^{\prime} \beta+X_{i k}{ }^{\prime} A X_{i k}+\varepsilon_{i k}$

with $X_{i k}=\left(\operatorname{lm}_{\mathrm{ik}}, \mathrm{lf}_{\mathrm{ik}}, Y_{\mathrm{ik}}\right)$. The components of $X_{i k}$ are disposable household income $(Y)$, the mother's leisure time $(l f)$, and the father's leisure time $(I m)$, which all vary by household $(i)$ and choice category $(k) . \varepsilon_{\mathrm{ik}}$ is an unobserved error term that is assumed to follow an extreme value distribution and to be independently distributed over households and choice categories. Matrix $A$ contains the coefficients of the quadratic terms and cross terms. Vector $\beta$ contains the coefficients of the linear terms. Preferences are allowed to vary across families through taste shifters of the linear terms. In particular, we include socio-demographic characteristics such as age, nationality of the father and mother, region of residence, disability, number of children, as observable characteristics explaining the variation in household preferences.

\section{Results}

Since the labor supply model is not the focus of this paper, we provide a detailed documentation of the results of the labor supply estimation in the Table A2 of the Appendix. The behavioral implications of the estimated labor supply model can most compactly be summarized by labor supply elasticities (Table A3 in the Appendix). These are plausible and in line with previous studies (Müller et al., 2015). In the following, we focus on the results of the policy simulation.

Simulation results for scenario A show that a family working time benefit that replaces about $65 \%$ of foregone net earnings for middle income families compared to full-time work would increase the share of couples where both partners choose to work around 30 hours per week from originally $1.5 \%$ by 0.9 percentage points (Table 3 ). While this seems like a very small effect in absolute terms, it is actually a rather large effect in relative terms: it translates to an increase in the share of couples

difficult to implement empirically (see, e.g., Blundell and MaCurdy, 1999). Moreover, the fact that time can only be divided between "market work" and "leisure" is not satisfying; rather, a third category "home production" would be appropriate. Unfortunately, this is not possible due to lack of a data set that contains reliable data on time allocation and market wages. 
choosing this working time arrangement by more than $60 \%$. The average working time of mothers would increase by $0.5 \%$, while fathers' working time would decrease by $0.2 \%$.

Table 3 Simulation results for scenario A (income replacement)

\begin{tabular}{|c|c|c|c|c|c|c|}
\hline & \multirow{2}{*}{$\begin{array}{l}\text { Original Share } \\
\text { of Couples } \\
\text { Choosing } \\
\text { "Family } \\
\text { Working Time" } \\
\text { (in \%) }\end{array}$} & \multirow{2}{*}{$\begin{array}{c}\text { Change in } \\
\text { Choice of } \\
\text { "Family } \\
\text { Working Time" } \\
\text { (in \%-points) }\end{array}$} & \multirow{2}{*}{$\begin{array}{c}\text { Change in } \\
\text { Choice of } \\
\text { "Family } \\
\text { Working Time" } \\
\text { (in \%) }\end{array}$} & \multirow{2}{*}{$\begin{array}{c}\text { Total Share of } \\
\text { Couples Choo- } \\
\text { sing "Family } \\
\text { Working Time" } \\
\text { after behavior- } \\
\text { ral response } \\
\text { (in \%) }\end{array}$} & \multicolumn{2}{|c|}{$\begin{array}{c}\text { Change in Working } \\
\text { Hours (in \%) }\end{array}$} \\
\hline & & & & & Women & Men \\
\hline All Couples & 1.46 & 0.89 & 60.96 & 2.35 & 0.52 & -0.22 \\
\hline West & 1.29 & 0.76 & 58.91 & 2.05 & 0.65 & -0.19 \\
\hline East & 2.35 & 1.52 & 64.68 & 3.87 & 0.19 & -0.37 \\
\hline $1^{\text {st }}$ quartile & 1.28 & 0.71 & 55.47 & 1.99 & 0.63 & -0.17 \\
\hline $2^{\text {nd }}$ quartile & 1.35 & 0.81 & 60.00 & 2.16 & 0.53 & -0.20 \\
\hline $3^{\text {rd }}$ quartile & 1.48 & 0.89 & 60.14 & 2.37 & 0.58 & -0.22 \\
\hline $4^{\text {th }}$ quartile & 1.97 & 1.33 & 67.51 & 3.3 & 0.31 & -0.34 \\
\hline 1 child & 1.72 & 1.06 & 61.63 & 2.78 & 0.51 & -0.27 \\
\hline$>1$ child & 1.32 & 0.79 & 59.85 & 2.11 & 0.52 & -0.19 \\
\hline
\end{tabular}

Source: SOEP 2010, 2011, 2012; FiD 2010, 2011, 2012; own calculations.

We also simulated the effects for several subgroups (Table 3). A comparison of couples in East and West Germany shows that this policy would lead to much larger behavioral responses in East Germany than in West Germany, at least in absolute terms. While in West Germany, the share of couples choosing this particular working time arrangement would increase by less than 0.8 percentage points (starting from roughly 1.3\%), in East Germany the increase amounts to more than 1.5 percentage points (starting from 2.35\%). It seems the social norms for mothers and fathers regarding working and caring still differ strongly between the two parts of the country (Blome, 2016a, b; Rosenfeld et al., 2004).

Moreover, we find that under scenario A, income replacement, the behavioral changes increase as family income increases. While the share of couples choosing the family working time model in the first income quartile only increases by 0.7 percentage points (starting from 1.3\%), the effect amounts to 1.3 percentage points for couples in the highest income quartile (starting from almost $2 \%$ ). In this 
income group, the share of couples choosing this particular working time arrangement is highest more than 3\%, taking behavioral changes into account.

The average results from scenario B, the lump sum benefit, are very similar to those from scenario A. This is not surprising since we chose the monthly amount of the lump sum benefit ( 250 Euro per month) to roughly equal the average amount of the income replacement benefit in scenario A. The share of couples choosing the family working time model would increase by almost 1 percentage point or $66 \%$ (Table 4 ).

Table $4 \quad$ Simulation results for scenario B (lump sum transfer)

\begin{tabular}{|c|c|c|c|c|c|c|}
\hline & \multirow{2}{*}{$\begin{array}{l}\text { Original Share } \\
\text { of Couples } \\
\text { Choosing } \\
\text { "Family } \\
\text { Working Time" } \\
\text { (in \%) }\end{array}$} & \multirow{2}{*}{$\begin{array}{c}\text { Change in } \\
\text { Choice of } \\
\text { "Family } \\
\text { Working Time" } \\
\text { (in \%-points) }\end{array}$} & \multirow{2}{*}{$\begin{array}{l}\text { Change in } \\
\text { Choice of } \\
\text { "Family } \\
\text { Working Time" } \\
\text { (in \%) }\end{array}$} & \multirow{2}{*}{$\begin{array}{l}\text { Total Share of } \\
\text { Couples Choo- } \\
\text { sing "Family } \\
\text { Working Time" } \\
\text { after behavior- } \\
\text { ral response } \\
\text { (in \%) }\end{array}$} & \multicolumn{2}{|c|}{$\begin{array}{c}\text { Change in Working } \\
\text { Hours (in \%) }\end{array}$} \\
\hline & & & & & Women & Men \\
\hline All Couples & 1.46 & 0.96 & 65.75 & 2.42 & 0.62 & -0.22 \\
\hline West & 1.29 & 0.78 & 60.47 & 2.07 & 0.74 & -0.18 \\
\hline East & 2.35 & 1.85 & 78.39 & 4.21 & 0.33 & -0.43 \\
\hline $1^{\text {st }}$ quartile & 1.28 & 0.91 & 70.54 & 2.20 & 0.90 & -0.19 \\
\hline $2^{\text {nd }}$ quartile & 1.35 & 0.92 & 68.15 & 2.27 & 0.66 & -0.21 \\
\hline $3^{\text {rd }}$ quartile & 1.48 & 0.98 & 66.22 & 2.46 & 0.69 & -0.23 \\
\hline $4^{\text {th }}$ quartile & 1.97 & 1.04 & 52.79 & 3.01 & 0.21 & -0.26 \\
\hline 1 child & 1.72 & 1.12 & 65.50 & 2.83 & 0.60 & -0.27 \\
\hline$>1$ child & 1.32 & 0.87 & 65.91 & 2.19 & 0.64 & -0.19 \\
\hline
\end{tabular}

Source: SOEP 2010, 2011, 2012; FiD 2010, 2011, 2012; own calculations.

The difference between East and West Germany is also quite similar to what we found for scenario A. However, we see a difference in the pattern of behavioral changes across income groups. In contrast to scenario A, which affected families with higher incomes more strongly than families with lower incomes, the behavioral effects are very similar across all income groups: The share of couples choosing this particular working hours arrangement would increase by roughly 1 percentage point in all income quartiles. This can be explained by the fact that the income replacement benefit in scenario A is more appealing to parents with higher earnings, while the lump sum benefit is more 
favorable to low income families. In quantitative terms, the difference between the two scenarios, however, is not very large: the income replacement benefit (scenario A) would lead to an increase of 1.3 percentage points, the lump-sum benefit (scenario B) to an increase of 1 percentage points in the share of couples in the upper income quartile who chose an egalitarian working time allocation of about 30 hours, respectively. Given that bureaucratic costs should be considerably lower in the lump sum benefit scenario (both for applicants and the administration) and that it would be more appealing to lower income couples, the lump-sum benefit might be the better choice.

It should be noted, however, that the results obtained from the econometric model must be interpreted with caution. One basic assumption in the behavioral model is that preferences do not change in case of a policy change, i.e. the introduction of the family working time model in our case. The simulated behavioral change is obtained from the adjustment of financial incentives holding all other factors constant. However, preferences and social norms change over time (Blome, 2016b). More importantly, the introduction of such a policy reform might, per se, change social norms even further (Brooks and Manza 2006, 2007; Kenworthy, 2009; Kenworthy and McCall, 2008). Moreover, existing restrictions, e.g. regarding the supply of subsidized childcare, which are not modeled explicitly here, might be reduced. Thus, our results should only be interpreted as short-run effects of these potential policy reforms and likely serve as lower-bound estimates. If social norms regarding the gender division of market and care work change, effects might be higher in the medium- and long-run.

\section{Discussion and policy conclusions}

The labor market engagement of women is steadily increasing, but the gender gap in family and care work has barely been affected by this development. Although many European countries have incorporated specific elements into existing or freshly introduced family policies that incentivize fathers to engage in child care (e.g. "daddy quota" in parental leave schemes), gender equality in the distribution of market work and care work is far from being achieved. At the same time, social value 
surveys show that norms and preferences are changing: In particular young parents demand a more equal sharing of gainful employment and family care between fathers and mothers. A significant share of young fathers state that they are not able to reduce their working hours according to their preferences for financial reasons.

In response, the proposed family working time model is part of the public debate in Germany. It presents a way to promote the dual earner/dual carer model among parents with young children. The core idea of the model is that parents are paid a financial benefit when both partners decide to work about 30 hours per week. If they both do so, each parent individually receives a financial transfer. Should only one partner opt for this working time and the other one works more (e.g. fulltime) or less (e.g. short part-time hours), then neither parent receives the benefit. The family working time model thus explicitly incentivizes the dual earner/dual carer model.

Our empirical analysis of the family working time model is applied to families with children aged 1 to 3 years in Germany. The model could increase the share of parents choosing this particular working time model by one percentage point. Given that the share of couples currently opting for this time allocation is low (about 1.5 percent), this is an increase of about 60 percent. The comparison of an income-replacing benefit with a lump-sum transfer sheds light on the distributional implications of the family working time model. Average effects are strikingly similar in both scenarios. A lump-sum transfer would, however, be more beneficial to parents with low incomes by evoking stronger behavioral reactions among them. Thus, this variant of the model offers a great opportunity for a more gender-egalitarian division of labor for families in the lower parts of the income distribution, a group traditionally lagging behind medium and high income families.

Although providing strong financial incentives, the behavioral changes induced by the model are relatively small, at least considered in absolute terms. According to our simulation results, the family working time model would not be able to close the gap between actual and preferred working arrangements in the short run. Solely improving financial incentives through a family working time 
benefit will not suffice to achieve that goal. Several additional areas have to be addressed: First, besides financial reasons, fathers often state that they are not able to decrease their working hours because of their workload or because of restrictions set by their employers. This points to the fact that cultural norms regarding gender stereotypes in the workplace, but also in terms of how employers define a "standard" employment relationship or whether they insist on a "culture of physical presence" at all times need to evolve as well. Second, the family working time model also needs to be complemented by readily available, affordable, and high-quality child care.

How do the results from our policy simulations for Germany generalize to other institutional contexts? Our descriptive analysis shows that the discrepancy between actual and desired working hours spans national boundaries and the different patterns for men and women are qualitatively similar. Differences are mostly driven by the current integration of women (and mothers) in the labor market and their actual hours of work. A regional comparison within Germany illustrates the likely effect of the family working time model in different contexts: The gender division of market and care work is currently more equal in East than West Germany. Thus, parents in East Germany would respond more strongly to the family working time model than those in West Germany. This is probably due to, first, social norms that are more favorable toward gender equality and, second, a historically much better child care infrastructure for children under the age of three. Policies setting financial incentives similar to the family working time model can, thusly, be expected to have greater effects in societies that already achieved a certain level of gender equality with respect to attitudes toward male and female working arrangements.

Finally, it should also be noted that from our simulation-based approach, we can only infer the shortrun effects of such a policy change. As an underlying assumption in the behavioral microsimulation model is that preferences stay constant as financial incentives are varied, the changes in social norms over time and, in particular, the change in social norms induced by a policy reform itself, mean that this approach is not appropriate for identifying medium- or long-term effects. To what extent such a 
policy would be able to impact attitudes and norms among employees and - even more importantly among employers remains a question for future research.

\section{References}

Aisenbrey, Silke, and Hannah Bruckner (2008) Occupational Aspirations and the Gender Gap in Wages, European Sociological Review 24 (5): 633-649.

Blome, Agnes (2016): The Politics of Work-Family Policy Reforms in Germany and Italy, Routledge, forthcoming.

Blome, Agnes (2016b): Normative Beliefs, Party Competition, and Work-Family Policy Reforms in Germany and Italy, Comparative Politics, 48(4), forthcoming.

Blundell, Richard and Thomas MaCurdy (1999): Labor supply: A review of alternative approaches, in Ashenfelter, Orley and David Card (eds.): Handbook of Labor Economics Vol. 3, 1559-1695.

Boeckmann, Irene, Joya Misra, and Michelle Budig (2015): Cultural and Institutional Factors Shaping Mothers' Employment and Working Hours in Postindustrial Countries, Social Forces 93(4): 13011333.

Brooks, Clem and Jeff Manza (2006): Social Policy Responsiveness in Developed Democracies, American Sociological Review 71(3): 474-494.

Brooks, Clem and Jeff Manza (2007): Why Welfare States Persist. The Importance of Public Opinion in Democracies, The University of Chicago Press.

Budig, Michelle J., Joya Misra, and Irene Boeckmann (2012): The Motherhood Penalty in CrossNational Perspective: The Importance of Work-Family Policies and Cultural Attitudes, Social Politics 19(2): 163-193.

Bühlmann, Felix, Guy Elcheroth, and Manuel Tettamanti (2010): The division of labour among European couples: The effects of life course and welfare policy on value-practice configurations, European Sociological Review (26): 49-66.

Bünning, Mareike, and Matthias Pollmann-Schult (2016): Family policies and fathers' working hours: cross-national differences in the paternal labour supply, Work, employment and society 30(2): 256274.

Ciccia, Rossella, and Inge Bleijenbergh (2014): After the Male Breadwinner Model? Childcare Services and the Division of Labor in European Countries, Social Politics: International Studies in Gender, State \& Society, 1-30.

Ciccia, Rosella and Mieke Verloo (2012): Parental leave regulations and the persistence of the male breadwinner model: Using fuzzy-set ideal type analysis to assess gender equality in an enlarged Europe, Journal of European Social Policy 22(5): 507-528.

Crompton, Rosemary (1999): Restructuring Gender Relations and Employment: The Decline of the Male Breadwinner, Oxford University Press. 
Dearing, Helene (2016): Gender equality in the division of work: How to assess European leave policies regarding their compliance with an ideal leave model, Journal of European Social Policy, forthcoming

Dotti Sani, Gulia Maria (2014): Men's Employment Hours and Time on Domestic Chores in European Countries, Journal of Family Issues 35(8): 1023-1047

Ekberg, John, Rickard Eriksson and Guido Friebel (2013): Parental Leave - A Policy Evaluation of the Swedish “Daddy Month" reform, Journal of Public Economics 97(1): 131-143.

Edlund, Jonas and Ida Öun (2016): Who should work and who should care? Attitudes towards the desirable division of labour between mothers and fathers in five European countries. Acta Sociologica 59(2): 151-196.

Ferragina, Emanuele and Martin Seeleib-Kaiser (2015): Determinants of a Silent (R)evolution: Understanding the Expansion of Family Policy in Rich OECD Countries, Social Politics 22(1): 1-37.

Geisler, Esther. and Michaela Kreyenfeld (2011): Against all odds: Fathers' use of parental leave in Germany, Journal of European Social Policy 21(1): 88-99.

Geyer, Johannes; Haan, Peter, and Katharina Wrohlich (2015): The effects of family policy on maternal labor supply: Combining evidence from a structural model and a quasi-experimental approach, Labour Economics, 36(C): 84-98.

Geyer, Johannes and Alexandra Krause (2016): Veränderungen der Erwerbsanreize für Mütter und Väter durch das Elterngeld Plus. DIW Discussion Paper 1592.

Gornick, Janet C. \& Meyers, Marcia K. (2003): Families That Work. Policies for Reconciling Parenthood and Employment, Russel Sage Foundation.

Hipp, Lena and Kathrin Leuze (2015): Institutionelle Determinanten einer partnerschaftlichen Aufteilung von Erwerbsarbeit in Europa und den USA, Kölner Zeitschrift für Soziologie und Sozialpsychologie, 67(4): 659-684.

Heckman, James J. (1979): Sample Selection Bias as a Specification Error, Econometrica 47(1): 153162.

Hook, Jennifer L. (2015): Incorporating 'class' into work-family arrangements: Insights from and for Three Worlds, Journal of European Social Policy 25(1): 14-31.

Huerta, Maria del Carmen, Willem Adema, Jennifer Baxter, Wen-Jui Han, Mette Lausten, Rae Hyuck Lee, and Jane Waldfogel (2013): Fathers' Leave, Fathers' Involvement and Child Development. Are They Related? Evidence from Four OECD Countries. OECD Social, Employment and Migration Working Papers, No. 140, OECD Publishing, Paris.

Keck, Wolfgang, and Chiara Saraceno (2013): The Impact of Different Social-Policy Frameworks on Social Inequalities among Women in the European Union: The Labour-Market Participation of Mothers, Social Politics: International Studies in Gender, State \& Society 20(3): 297-328.

Kenworthy, Lane (2009): The effect of public opinion on social policy generosity, Socio-Economic Review 7(4): 727-740.

Kenworthy, Lane and Leslie McCall (2008): Inequality, public opinion and redistribution, SocioEconomic Review 6(1): 35-68. 
Kleider, Hanna (2015): Paid and unpaid work: The impact of social policies on the gender division of labour, Journal of European Social Policy 25(5): 505-520.

Korpi, Walter, Tommy Ferrarini, and Stefan Englund (2013): Women's Opportunities under Different Family Policy Constellations: Gender, Class, and Inequality Tradeoffs in Western Countries Reexamined, Social Politics: International Studies in Gender, State \& Society 20(1): 1-40.

Lewis, Jane (2009): Work-Family Balance, Gender and Policy, Edward Elgar.

Lewis, Jane, Mary Campbell and Carmen Huerta (2008): Patterns of paid and unpaid work in Western Europe: gender, commodification, preferences and the implications for policy, Journal of European Social Policy 18(1): 21-37.

Maume, David J. (2008): Gender Differences in Providing Urgent Childcare among Dual-Earner Parents, Social Forces 87(1): 273-297.

Morgan, Kimberly J. (2008): The Political Path to a Dual Earner/Dual Carer Society: Pitfalls and Possibilities, Politics \& Society 36(3): 403-420.

Mutari, Ellen and Deborah M. Figart (2001): Europe at a Crossroads: Harmonization, Liberalization, and the Gender of Work Time, Social Politics 8(1): 36-64.

Müller, Kai-Uwe, Neumann, Michael and Katharina Wrohlich (2013): Bessere Vereinbarkeit von Familie und Beruf durch eine neue Lohnersatzleistung bei Familienarbeitszeit, DIW Wochenbericht 46/2013: 3-11.

Müller, Kai-Uwe, Neumann, Michael and Katharina Wrohlich (2015): Familienarbeitszeit Reloaded: Vereinfachung durch pauschalierte Leistung und Flexibilisierung durch Arbeitszeitkorridor, DIW Politikberatung kompakt No. 105, German Institute for Economic Research (DIW Berlin).

Müller, Kai-Uwe, and Katharina Wrohlich (2016): Two Steps Forward - One Step Back? Evaluating Contradicting Child Care Policies in Germany, CESifo Economic Studies, forthcoming.

OECD Family database (www.oecd.org/social/family/databases; retrieved April 25th 2016 ).

OECD (2011): "Reducing barriers to parental employment", in: Doing Better for Families, OECD Publishing, Paris.

Pascall, Gillian and Jane Lewis (2004): Emerging Gender Regimes and Policies for Gender Equality in a Wider Europe, Journal of Social Policy 33(3): 373-394.

Pettit, Becky, and Jennifer L. Hook (2009): Gendered Tradeoffs, New York: Russell Sage Foundation Press.

Pfau-Effinger, Birgit (1999): Change of family policies in the socio-cultural context of European Societies, Comparative Social Research 18:135-160.

Pollmann-Schult, Matthias (2016): What mothers want: The impact of structural and cultural factors on mothers' preferred working hours in Western Europe, Advances in Life Course Research, forthcoming.

Ponthieux, Sophie and Dominique Meurs (2015): Gender Inequality, in: Atkinson, Anthony B. and François Bourguignon (eds.): Handbook of Income Distribution Vol. 2, 981-1146. 
Ray, Rebecca, Janet C. Gornick and John Schmitt (2010): Who cares? Assessing generosity and gender equality in parental leave policy designs in 21 countries, Journal of European Social Policy 20(3): 196216.

Rosenfeld, Rachel A., Trappe, Heike and Janet C. Gornick (2004), Gender and Work in Germany: Before and After Reunification, Annual Review of Sociology 30: 103-124.

Schröder, Mathis, Rainer Siegers, and C. Katharina Spieß (2013) "Familien in Deutschland" - FiD, Schmollers Jahrbuch 133 (4): 595-606.

Steiber, Nadia and Barbara Haas (2012): Advances in explaining women's employment patterns, Socio-Economic Review 10(2): 343-367

Steiber, Nadia and Barbara Haas (2015): Overworked or Underemployed? Actual and Preferred Household Employment Patterns in the Context of the Economic Crisis, VID Working Paper No. 07/2015, Vienna Institute of Demography (VID), Austrian Academy of Sciences

Steiner, Viktor, Katharina Wrohlich, Peter Haan and Johannes Geyer (2012): Documentation of the Tax-Benefit Microsimulation Model STSM, Version 2012. DIW Data Documentation No 63.

Trappe, Heike, Matthias Pollmann-Schult, and Christian Schmitt (2015): The Rise and Decline of the Male Breadwinner Model: Institutional Underpinnings and Future Expectations, European Sociological Review 31(2): 230-242.

Van der Lippe, Tanja, de Ruijter, Judith, Ruijter, Esther de and Werner Raub (2011): Persistent Inequalities in Time Use between Men and Women: A Detailed Look at the Influence of Economic Circumstances, Policies, and Culture, European Sociological Review (27)2: 164-179.

van Soest, Arthur (1995): Structural Models of Family Labor Supply: A Discrete Choice Approach The Journal of Human Resources, 30: 63-88. 


\section{Appendix}

Table A1 Descriptive statistics: actual and preferred working hours

\begin{tabular}{|c|c|c|c|c|c|c|c|c|c|c|c|}
\hline \multirow[t]{3}{*}{ Country } & \multirow{3}{*}{$\begin{array}{l}\text { Hours } \\
\text { category }\end{array}$} & \multicolumn{5}{|c|}{ Women } & \multicolumn{5}{|c|}{ Men } \\
\hline & & \multirow{2}{*}{$\begin{array}{l}\begin{array}{l}\text { Actual } \\
\text { hours }\end{array} \\
\text { Share } \\
\text { in cat. }\end{array}$} & \multicolumn{4}{|c|}{$\begin{array}{c}\text { Thereof by hours category } \\
\text { desired hours }\end{array}$} & \multirow{2}{*}{$\begin{array}{l}\begin{array}{c}\text { Actual } \\
\text { hours }\end{array} \\
\text { Share } \\
\text { in cat. }\end{array}$} & \multicolumn{4}{|c|}{$\begin{array}{c}\text { Thereof by hours category } \\
\text { desired hours }\end{array}$} \\
\hline & & & $\begin{array}{l}\text { Share }^{1} \text { in- } \\
\text { creasing }^{-}\end{array}$ & $\begin{array}{l}\text { Avg. hours } \\
\text { increase }\end{array}$ & $\begin{array}{l}\text { Share }^{1} \text { de- } \\
\text { creasing }\end{array}$ & $\begin{array}{l}\text { Avg. hours } \\
\text { decrease }\end{array}$ & & $\begin{array}{l}\text { Share }^{1} \text { in- } \\
\text { creasing }\end{array}$ & $\begin{array}{l}\text { Avg. hours } \\
\text { increase }\end{array}$ & $\begin{array}{l}\text { Share }^{1} \text { de- } \\
\text { creasing }\end{array}$ & $\begin{array}{l}\text { Avg. hours } \\
\text { decrease }\end{array}$ \\
\hline \multirow{5}{*}{$\begin{array}{l}\text { Ger- } \\
\text { many }\end{array}$} & 0 & 0.101 & 0.877 & 25.1 & 0.000 & & 0.068 & 1.000 & 39.2 & 0.000 & \\
\hline & $1-24$ & 0.300 & 0.523 & 9.8 & 0.187 & -6.4 & 0.076 & 0.854 & 26.9 & 0.000 & \\
\hline & $25-35$ & 0.170 & 0.147 & 8.1 & 0.435 & -9.4 & 0.092 & 0.538 & 5.4 & 0.035 & -8.0 \\
\hline & $>35$ & 0.429 & 0.000 & & 0.887 & -17.2 & 0.764 & 0.176 & 4.0 & 0.450 & -11.4 \\
\hline & Total & 1.000 & 0.297 & 11.6 & 0.448 & -13.6 & 1.000 & 0.231 & 7.9 & 0.400 & -11.4 \\
\hline \multirow{5}{*}{$\begin{array}{l}\text { Great } \\
\text { Britain }\end{array}$} & 0 & 0.034 & 0.507 & 26.6 & 0.000 & & 0.010 & 1.000 & 26.8 & 0.000 & \\
\hline & $1-24$ & 0.379 & 0.356 & 11.6 & 0.185 & -8.1 & 0.039 & 0.500 & 17.0 & 0.404 & -11.8 \\
\hline & $25-35$ & 0.261 & 0.134 & 5.8 & 0.463 & -12.7 & 0.126 & 0.323 & 8.3 & 0.484 & -14.6 \\
\hline & $>35$ & 0.327 & 0.014 & 5.0 & 0.713 & -17.9 & 0.826 & 0.192 & 7.8 & 0.411 & -14.2 \\
\hline & Total & 1.000 & 0.192 & 11.7 & 0.424 & -14.8 & 1.000 & 0.229 & 9.5 & 0.415 & -14.1 \\
\hline \multirow[t]{5}{*}{ Ireland } & 0 & 0.106 & 0.525 & 25.2 & 0.000 & & 0.013 & 1.000 & 33.0 & 0.000 & \\
\hline & $1-24$ & 0.316 & 0.362 & 11.8 & 0.186 & -12.3 & 0.067 & 0.720 & 17.5 & 0.000 & \\
\hline & $25-35$ & 0.202 & 0.142 & 9.9 & 0.492 & -11.8 & 0.091 & 0.515 & 9.0 & 0.098 & -14.3 \\
\hline & $>35$ & 0.375 & 0.028 & 4.7 & 0.772 & -21.6 & 0.830 & 0.190 & 8.2 & 0.433 & -16.9 \\
\hline & Total & 1.000 & 0.210 & 14.8 & 0.448 & -18.2 & 1.000 & 0.265 & 11.2 & 0.369 & -16.9 \\
\hline \multirow[t]{5}{*}{ France } & 0 & 0.058 & 0.725 & 27.4 & 0.000 & & 0.000 & & & & \\
\hline & $1-24$ & 0.179 & 0.468 & 11.1 & 0.167 & -11.5 & 0.017 & 1.000 & 14.4 & 0.000 & \\
\hline & $25-35$ & 0.537 & 0.249 & 6.0 & 0.335 & -12.2 & 0.539 & 0.418 & 5.7 & 0.188 & -22.7 \\
\hline & $>35$ & 0.227 & 0.169 & 2.3 & 0.646 & -10.3 & 0.444 & 0.498 & 8.3 & 0.337 & -16.1 \\
\hline & Total & 1.000 & 0.298 & 10.0 & 0.356 & -11.4 & 1.000 & 0.464 & 7.3 & 0.251 & -18.8 \\
\hline \multirow[t]{5}{*}{ Belgium } & 0 & 0.046 & 0.774 & 24.2 & 0.000 & & 0.000 & & & & \\
\hline & $1-24$ & 0.308 & 0.399 & 10.7 & 0.083 & -3.8 & 0.044 & 0.762 & 21.1 & 0.000 & \\
\hline & $25-35$ & 0.281 & 0.167 & 7.4 & 0.436 & -10.0 & 0.037 & 0.476 & 16.4 & 0.000 & \\
\hline & $>35$ & 0.365 & 0.036 & 6.0 & 0.685 & -13.7 & 0.919 & 0.269 & 6.6 & 0.278 & -8.3 \\
\hline & Total & 1.000 & 0.219 & 11.9 & 0.398 & -11.9 & 1.000 & 0.298 & 8.8 & 0.256 & -8.3 \\
\hline \multirow{5}{*}{$\begin{array}{l}\text { Nether- } \\
\text { lands }\end{array}$} & 0 & 0.019 & 0.659 & 26.2 & 0.000 & & 0.005 & 0.000 & & 0.000 & \\
\hline & $1-24$ & 0.588 & 0.266 & 6.3 & 0.219 & -10.8 & 0.026 & 0.272 & 19.0 & 0.225 & -8.0 \\
\hline & $25-35$ & 0.218 & 0.101 & 5.7 & 0.390 & -8.9 & 0.110 & 0.197 & 4.1 & 0.248 & -15.9 \\
\hline & $>35$ & 0.175 & 0.026 & 6.0 & 0.706 & -22.7 & 0.859 & 0.095 & 5.6 & 0.495 & -13.3 \\
\hline & Total & 1.000 & 0.196 & 7.5 & 0.337 & -14.7 & 1.000 & 0.111 & 6.2 & 0.458 & -13.4 \\
\hline \multirow{5}{*}{$\begin{array}{l}\text { Den- } \\
\text { mark }\end{array}$} & 0 & 0.005 & 0.000 & & 0.000 & & 0.000 & & & & \\
\hline & $1-24$ & 0.071 & 0.737 & 15.2 & 0.027 & -15.0 & 0.019 & 1.000 & 14.6 & 0.000 & \\
\hline & $25-35$ & 0.405 & 0.192 & 3.9 & 0.234 & -11.7 & 0.031 & 0.861 & 8.4 & 0.000 & \\
\hline & $>35$ & 0.518 & 0.044 & 6.8 & 0.487 & -9.9 & 0.950 & 0.177 & 8.3 & 0.246 & -14.1 \\
\hline & Total & 1.000 & 0.153 & 8.2 & 0.349 & -10.4 & 1.000 & 0.213 & 8.9 & 0.234 & -14.1 \\
\hline \multirow[t]{5}{*}{ Finland } & 0 & 0.010 & 1.000 & 25.2 & 0.000 & & 0.020 & 1.000 & 36.3 & 0.000 & \\
\hline & $1-24$ & 0.073 & 0.689 & 20.5 & 0.100 & -3.0 & 0.033 & 0.865 & 25.0 & 0.000 & \\
\hline & $25-35$ & 0.207 & 0.257 & 8.9 & 0.176 & -7.6 & 0.045 & 0.698 & 7.7 & 0.107 & -15.0 \\
\hline & $>35$ & 0.711 & 0.073 & 2.5 & 0.471 & -11.3 & 0.902 & 0.246 & 5.5 & 0.285 & -11.2 \\
\hline & Total & 1.000 & 0.165 & 11.4 & 0.378 & -10.8 & 1.000 & 0.302 & 9.6 & 0.262 & -11.2 \\
\hline \multirow[t]{5}{*}{ Sweden } & 0 & 0.019 & 0.704 & 40.0 & 0.000 & & 0.000 & & & & \\
\hline & $1-24$ & 0.112 & 0.524 & 14.9 & 0.175 & -4.0 & 0.015 & 0.000 & & 0.000 & \\
\hline & $25-35$ & 0.277 & 0.192 & 6.8 & 0.133 & -4.7 & 0.071 & 0.437 & 9.7 & 0.184 & -11.3 \\
\hline & $>35$ & 0.591 & 0.060 & 2.7 & 0.491 & -10.1 & 0.915 & 0.157 & 4.8 & 0.338 & -12.4 \\
\hline & Total & 1.000 & 0.161 & 11.6 & 0.347 & -9.2 & 1.000 & 0.174 & 5.7 & 0.323 & -12.4 \\
\hline Cyprus & 0 & 0.102 & 0.460 & 31.0 & 0.000 & & 0.000 & & & & \\
\hline & $1-24$ & 0.038 & 0.410 & 12.4 & 0.293 & -18.0 & 0.000 & & & & \\
\hline & $25-35$ & 0.104 & 0.223 & 22.2 & 0.588 & -26.9 & 0.089 & 0.519 & 5.5 & 0.321 & -33.1 \\
\hline & $>35$ & 0.756 & 0.040 & 8.8 & 0.648 & -19.7 & 0.911 & 0.128 & 11.1 & 0.469 & -26.9 \\
\hline & Total & 1.000 & 0.116 & 20.9 & 0.562 & -20.4 & 1.000 & 0.162 & 9.5 & 0.456 & -27.3 \\
\hline
\end{tabular}

Notes: 1 - shares plus share of people satisfied with their working hours add up to one in each row.

Source: European Social Survey 2010; own calculations. 
Table A1 (ctd.) Descriptive statistics: actual and preferred working hours

\begin{tabular}{|c|c|c|c|c|c|c|c|c|c|c|c|}
\hline \multirow[t]{3}{*}{ Country } & \multirow{3}{*}{$\begin{array}{l}\text { Hours } \\
\text { category }\end{array}$} & \multicolumn{5}{|c|}{ Women } & \multicolumn{5}{|c|}{ Men } \\
\hline & & \multirow{2}{*}{$\begin{array}{l}\text { Actual } \\
\text { hours } \\
\text { Share } \\
\text { in cat. }\end{array}$} & \multicolumn{4}{|c|}{$\begin{array}{l}\text { Thereof by hours category } \\
\text { desired hours }\end{array}$} & \multirow{2}{*}{$\begin{array}{l}\begin{array}{l}\text { Actual } \\
\text { hours }\end{array} \\
\text { Share } \\
\text { in cat. }\end{array}$} & \multicolumn{4}{|c|}{$\begin{array}{l}\text { Thereof by hours category } \\
\text { desired hours }\end{array}$} \\
\hline & & & $\begin{array}{l}\text { Share }^{1} \text { in- } \\
\text { creasing }\end{array}$ & $\begin{array}{l}\text { Avg. hours } \\
\text { increase }\end{array}$ & $\begin{array}{c}\text { Share }^{1} \text { de- } \\
\text { creasing }\end{array}$ & $\begin{array}{l}\text { Avg. hours } \\
\text { decrease }\end{array}$ & & $\begin{array}{l}\text { Share }^{1} \text { in } \\
\text { creasing }\end{array}$ & $\begin{array}{l}\text { Avg. hours } \\
\text { increase }\end{array}$ & $\begin{array}{l}\text { Share }{ }^{1} \text { de- } \\
\text { creasing }\end{array}$ & $\begin{array}{l}\text { Avg. hours } \\
\text { decrease }\end{array}$ \\
\hline \multirow[t]{5}{*}{ Spain } & 0 & 0.106 & 0.593 & 28.3 & 0.000 & & 0.000 & & & & \\
\hline & $1-24$ & 0.111 & 0.688 & 19.6 & 0.038 & -4.0 & 0.040 & 0.819 & 24.9 & 0.181 & -15.0 \\
\hline & $25-35$ & 0.222 & 0.227 & 8.1 & 0.338 & -12.4 & 0.108 & 0.267 & 5.8 & 0.240 & -8.8 \\
\hline & $>35$ & 0.561 & 0.023 & 1.9 & 0.616 & -15.4 & 0.852 & 0.113 & 14.8 & 0.343 & -11.5 \\
\hline & Total & 1.000 & 0.202 & 18.4 & 0.424 & -14.7 & 1.000 & 0.158 & 15.3 & 0.325 & -11.4 \\
\hline \multirow[t]{5}{*}{ Greece } & 0 & 0.384 & 0.718 & 34.9 & 0.000 & & 0.036 & 0.517 & 28.5 & 0.000 & \\
\hline & $1-24$ & 0.062 & 0.872 & 17.1 & 0.036 & -14.0 & 0.015 & 1.000 & 43.8 & 0.000 & \\
\hline & $25-35$ & 0.079 & 0.597 & 11.6 & 0.203 & -15.8 & 0.123 & 0.599 & 7.4 & 0.099 & -29.0 \\
\hline & $>35$ & 0.474 & 0.153 & 9.6 & 0.359 & -23.6 & 0.826 & 0.195 & 13.8 & 0.239 & -23.9 \\
\hline & Total & 1.000 & 0.450 & 26.3 & 0.188 & -22.9 & 1.000 & 0.268 & 14.7 & 0.210 & -24.2 \\
\hline \multirow[t]{5}{*}{ Portugal } & 0 & 0.004 & 1.000 & 8.0 & 0.000 & & 0.005 & 1.000 & 40.0 & 0.000 & \\
\hline & $1-24$ & 0.128 & 0.508 & 24.8 & 0.000 & & 0.032 & 0.590 & 17.5 & 0.000 & \\
\hline & $25-35$ & 0.183 & 0.448 & 5.7 & 0.010 & -23.0 & 0.064 & 0.789 & 7.7 & 0.000 & \\
\hline & $>35$ & 0.685 & 0.187 & 8.2 & 0.157 & -14.6 & 0.899 & 0.395 & 11.0 & 0.130 & -8.0 \\
\hline & Total & 1.000 & 0.279 & 11.3 & 0.109 & -14.7 & 1.000 & 0.429 & 11.2 & 0.117 & -8.0 \\
\hline \multirow[t]{5}{*}{ Bulgaria } & 0 & 0.051 & 1.000 & 36.4 & 0.000 & & 0.007 & 1.000 & 45.7 & 0.000 & \\
\hline & $1-24$ & 0.033 & 1.000 & 21.5 & 0.000 & & 0.039 & 1.000 & 24.1 & 0.000 & \\
\hline & $25-35$ & 0.031 & 0.841 & 9.0 & 0.000 & & 0.044 & 0.822 & 13.6 & 0.079 & -5.0 \\
\hline & $>35$ & 0.884 & 0.163 & 10.4 & 0.196 & -15.1 & 0.910 & 0.255 & 10.4 & 0.156 & -13.2 \\
\hline & Total & 1.000 & 0.254 & 16.9 & 0.173 & -15.1 & 1.000 & 0.314 & 13.3 & 0.146 & -13.1 \\
\hline Czech & 0 & 0.046 & 1.000 & 34.8 & 0.000 & & 0.007 & 1.000 & 48.0 & 0.000 & \\
\hline \multirow[t]{4}{*}{ Republic } & $1-24$ & 0.046 & 0.553 & 21.0 & 0.332 & -3.3 & 0.022 & 1.000 & 31.2 & 0.000 & \\
\hline & $25-35$ & 0.066 & 0.092 & 10.0 & 0.506 & -21.5 & 0.009 & 0.553 & 5.0 & 0.447 & -35.0 \\
\hline & $>35$ & 0.842 & 0.312 & 7.6 & 0.401 & -27.5 & 0.962 & 0.457 & 10.1 & 0.286 & -27.7 \\
\hline & Total & 1.000 & 0.340 & 12.3 & 0.387 & -26.0 & 1.000 & 0.474 & 11.6 & 0.279 & -27.8 \\
\hline \multirow[t]{5}{*}{ Estonia } & 0 & 0.021 & 1.000 & 39.2 & 0.000 & & 0.000 & & & & \\
\hline & $1-24$ & 0.087 & 0.846 & 25.4 & 0.000 & & 0.033 & 0.638 & 47.3 & 0.000 & \\
\hline & $25-35$ & 0.103 & 0.467 & 12.6 & 0.303 & -19.2 & 0.038 & 0.730 & 37.7 & 0.270 & -16.5 \\
\hline & $>35$ & 0.790 & 0.149 & 25.8 & 0.372 & -22.3 & 0.929 & 0.199 & 23.7 & 0.261 & -29.6 \\
\hline & Total & 1.000 & 0.260 & 24.3 & 0.325 & -22.0 & 1.000 & 0.233 & 27.5 & 0.253 & -29.1 \\
\hline Hungary & 0 & 0.054 & 0.783 & 41.8 & 0.000 & & 0.000 & & & & \\
\hline & $1-24$ & 0.074 & 0.858 & 21.1 & 0.072 & -20.0 & 0.019 & 0.270 & 3.0 & 0.177 & -5.0 \\
\hline & $25-35$ & 0.068 & 0.729 & 10.9 & 0.201 & -16.2 & 0.024 & 0.851 & 19.6 & 0.149 & -35.0 \\
\hline & $>35$ & 0.805 & 0.263 & 10.8 & 0.256 & -25.5 & 0.957 & 0.478 & 14.2 & 0.141 & -27.7 \\
\hline & Total & 1.000 & 0.366 & 16.2 & 0.225 & -24.9 & 1.000 & 0.483 & 14.3 & 0.142 & -27.4 \\
\hline Latvia & 0 & 0.057 & 0.899 & 31.8 & 0.000 & & 0.002 & 1.000 & 40.0 & 0.000 & \\
\hline & $1-24$ & 0.111 & 0.873 & 30.9 & 0.000 & & 0.004 & 0.087 & 20.0 & 0.000 & \\
\hline & $25-35$ & 0.018 & 0.510 & 14.8 & 0.000 & & 0.013 & 0.661 & 14.4 & 0.000 & \\
\hline & $>35$ & 0.815 & 0.097 & 7.7 & 0.270 & -11.8 & 0.981 & 0.336 & 9.6 & 0.169 & -14.8 \\
\hline & Total & 1.000 & 0.236 & 22.7 & 0.220 & -11.8 & 1.000 & 0.340 & 9.9 & 0.166 & -14.8 \\
\hline Poland & 0 & 0.049 & 0.548 & 40.0 & 0.000 & & 0.000 & & & & \\
\hline & $1-24$ & 0.113 & 0.963 & 21.4 & 0.037 & -1.0 & 0.062 & 0.907 & 25.4 & 0.093 & -5.0 \\
\hline & $25-35$ & 0.077 & 0.693 & 12.1 & 0.175 & -29.3 & 0.031 & 0.606 & 14.7 & 0.394 & -27.6 \\
\hline & $>35$ & 0.761 & 0.346 & 9.7 & 0.283 & -33.1 & 0.908 & 0.561 & 15.8 & 0.234 & -32.6 \\
\hline & Total & 1.000 & 0.452 & 14.6 & 0.233 & -32.3 & 1.000 & 0.584 & 16.7 & 0.230 & -31.7 \\
\hline Slovakia & 0 & 0.033 & 0.850 & 36.8 & 0.000 & & 0.011 & 0.667 & 30.0 & 0.000 & \\
\hline & $1-24$ & 0.048 & 0.719 & 19.9 & 0.281 & -16.2 & 0.008 & 0.000 & & 1.000 & -13.1 \\
\hline & $25-35$ & 0.036 & 0.532 & 13.2 & 0.207 & -22.7 & 0.010 & 0.404 & 5.0 & 0.596 & -4.0 \\
\hline & $>35$ & 0.883 & 0.247 & 7.7 & 0.383 & -20.1 & 0.970 & 0.359 & 10.8 & 0.302 & -22.9 \\
\hline & Total & 1.000 & 0.300 & 12.2 & 0.359 & -20.0 & 1.000 & 0.360 & 11.1 & 0.307 & -22.3 \\
\hline Overall & 0 & 0.062 & 0.695 & 30.4 & 0.000 & & 0.005 & 0.874 & 34.5 & 0.000 & \\
\hline & $1-24$ & 0.243 & 0.483 & 12.8 & 0.163 & -8.2 & 0.031 & 0.763 & 22.9 & 0.130 & -11.3 \\
\hline & $25-35$ & 0.246 & 0.227 & 7.5 & 0.357 & -11.8 & 0.160 & 0.418 & 6.6 & 0.208 & -18.9 \\
\hline & $>35$ & 0.450 & 0.136 & 8.3 & 0.521 & -18.1 & 0.804 & 0.271 & 10.3 & 0.345 & -15.1 \\
\hline & Total & 1.000 & 0.277 & 13.5 & 0.361 & -15.5 & 1.000 & 0.313 & 10.8 & 0.314 & -15.5 \\
\hline
\end{tabular}

Notes: 1 - shares plus share of people satisfied with their working hours add up to one in each row.

Source: European Social Survey 2010; own calculations. 


\section{Table A2 Conditional labor supply model}

\begin{tabular}{|c|c|c|}
\hline & Coefficient & Standard Error \\
\hline Log net income & $1.44 * * *$ & 0.23 \\
\hline Log net income squared & $0.12 *$ & 0.07 \\
\hline Log mother's leisure & $1.63^{* * *}$ & 0.09 \\
\hline Log mother's leisure squared & $0.25^{* * *}$ & 0.03 \\
\hline Log father's leisure & 0.06 & 0.09 \\
\hline Log father's leisure squared & $0.34^{* * *}$ & 0.04 \\
\hline Interactions & & \\
\hline Log net income & & \\
\hline$x$ Age mother & $0.38 * * *$ & 0.09 \\
\hline x Age father & -0.18 & 0.13 \\
\hline x German & $0.67^{* * *}$ & 0.22 \\
\hline x East German & 0.31 & 0.27 \\
\hline Log Mother's leisure & & \\
\hline$x$ Age & 0.04 & 0.04 \\
\hline $\mathrm{x}$ Age squared & $13.32 * * *$ & 2.33 \\
\hline x German & $-0.30 * * *$ & 0.08 \\
\hline x East German & $-0.66 * * *$ & 0.09 \\
\hline x Handicapped 1-50\% & -0.10 & 0.12 \\
\hline x Handicapped $>50 \%$ & $0.88 * * *$ & 0.33 \\
\hline$x$ One child & $0.12 * *$ & 0.06 \\
\hline x Two children & $-0.17^{* * *}$ & 0.05 \\
\hline x Three children & $-0.25^{* * *}$ & 0.06 \\
\hline Log Father's leisure & & \\
\hline$x$ Age & $-0.16^{* *}$ & 0.06 \\
\hline x Age squared & $23.71 * * *$ & 4.52 \\
\hline x German & $-0.21 * * *$ & 0.08 \\
\hline x East German & $0.21 *$ & 0.11 \\
\hline x Handicapped $1-50 \%$ & $0.39 * *$ & 0.15 \\
\hline x Handicapped $>50 \%$ & 0.41 & 0.27 \\
\hline Crossed & & \\
\hline Net income $x$ mother's leisure & $-0.14 * * *$ & 0.05 \\
\hline Net income $x$ father's leisure & $0.19 * * *$ & 0.06 \\
\hline Mother's leisure $x$ father's leisure & 0.05 & 0.04 \\
\hline $\mathrm{N}$ & \multicolumn{2}{|c|}{83,375} \\
\hline$\|$ & \multicolumn{2}{|c|}{$-8,665$} \\
\hline chi2 & \multicolumn{2}{|c|}{4,140} \\
\hline
\end{tabular}

Notes: Mother (father)'s leisure is interacted with her (his) characteristics. (East) German interacted with net income is defined as at least one spouse having that characteristic.

Source: SOEP 2010, 2011, 2012; FiD 2010, 2011, 2012; own calculations. 


\section{Table A3 Wage elasticities}

\begin{tabular}{l|c|c|c|c}
\hline & \multicolumn{2}{|c|}{ Women } & \multicolumn{2}{c}{ Men } \\
\hline & $\begin{array}{c}\text { Change in hours } \\
\text { (in \%) }\end{array}$ & $\begin{array}{c}\text { Change in } \\
\text { participation rates } \\
\text { (in \%-points) }\end{array}$ & $\begin{array}{c}\text { Change in hours } \\
\text { (in \%) }\end{array}$ & $\begin{array}{c}\text { Change in } \\
\text { participation rates } \\
\text { (in \%-points) }\end{array}$ \\
\hline All & 0.17 & 0.14 & 0.02 & 0.03 \\
East Germany & 0.18 & 0.14 & 0.02 & 0.03 \\
West Germany & 0.14 & 0.14 & 0.04 & 0.04 \\
\hline
\end{tabular}

Notes: Changes in hours are measured conditional on already being employed.

Source: SOEP 2010, 2011, 2012; FiD 2010, 2011, 2012; own calculations. 